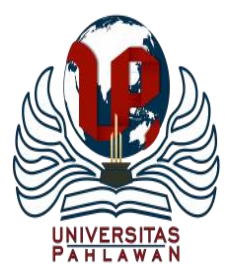

Edukatif : Jurnal Ilmu Pendidikan Volume 3 Nomor 1 Tahun 2021 Halm 1 - 7 EDUKATIF: JURNAL ILMU PENDIDIKAN

Research \& Learning in Education

https://edukatif.org/index.php/edukatif/index

\title{
Analisis Tahapan dalam Belajar Verbal
}

\author{
Hasan Basri $^{1 凶}$, Neviyarni $^{2}$
}

Universitas Negeri Padang, Indonesia ${ }^{1,2}$

E-mail : hasanbasri0293@ gmail.com ${ }^{1} \underline{\text { neviyarni.suhaili911@ @mail.com }}^{2}$

\begin{abstract}
Abstrak
Artikel ini membahas tentang analisis tahapan dalam belajar verbal menggunakan rujukan dari kajian literatur yang relevan, dalam konsepnya belajar verbal (verbal learning) merupakan kegiatan pembelajaran yang mendorong siswa untuk memberikan respon terhadap materi verbal seperti sebuah kata dan tanggapantanggapan yang bersifat verbal, ruang lingkup belajar verbal terdiri dari materi dan prosedur yang terurai dalam konteks-konteks pengembangan yaitu, Serial Learning, Paired Assosiated Learning, Free Recall,dan Recognation Learning. Adapun tahap-tahap dalam belajar verbal yaitu, respon dan stimulus learning, stimulus dan descrimination, stimulus selection, dan stimulus coding.
\end{abstract}

Kata kunci: belajar verbal

\section{Abstract}

This article discusses the analysis of stages in verbal learning using references from relevant literature studies, in the concept verbal learning (verbal learning) is a learning activity that encourages students to respond to verbal material such as a word and responses that are verbal in nature. Verbal learning consists of materials and procedures that break down in development contexts, namely, Serial Learning, Paired Associated Learning, Free Recall, and Recognation Learning. As for the stages in verbal learning, namely, response and stimulus learning, stimulus and descrimination, stimulus selection, and stimulus coding.

Keywords: verbal learning

Copyright (c) 2021 Hasan Basri, Neviyarni

$\checkmark$ Corresponding author

Email : hasanbasri0293@gmail.com

DOI: https://doi.org/10.31004/edukatif.v3i1.171

ISSN 2656-8063 (Media Cetak)

ISSN 2656-8071 (Media Online) 


\section{PENDAHULUAN}

Berbicara merupakan aspek yang tidak terlepas dalam konteks kehidupan manusia, bahkan ketika dilahirkan kedunia manusia sudah berinteraksi melalui tangisannya, ketika melakukan kegiatan belajar manusia menggunakan bahasa verbal, tujuan belajar verbal untuk memahami pemaknaan dari kata asing, memahami berbagai aspek yang abstrak seperti undang- undang hak dan lain sebagainya. Dalam konteks pembelajaran, untuk menyajikan materi terhadap siswa semestinya disajikan dalam bahasa yang komunikatif, disamping itu ekpresi wajah dan gestur tubuh merupakan bagian dari bahasa verbal yang semestinya harus diperhatikan, dalam interaksi pembelajaran semestinya guru dan siswa dapat saling memahami berbagai bahasa verbal agar tercipta komunikasi yang efektif baik melalui lisan maupun dengan bahasa tubuh (Han \& goleman, daniel; boyatzis, Richard; Mckee, 2019).

Bahasa yang jelas dapat menciptakan komunikasi yang baik dan efektif, meskipun dilakukan dalam bentuk bahasa verbal, demikian juga informasi yang ingin disampaikan akan mudah dipahami jika disampaikan dengan bahasa yang baik, dengan demikian dibutuhkan peran guru dalam mengolah kompetensi verbal yang dimiliki untuk melakukan interaksi dengan siswa dalam kegiatan pembelajaran, aspek berbahasa merupakan salah satu kunci keberhasilan dalam suatu pembelajaran, bahasa merupakan cerminan yang ada pada jiwa seseorang, sebab kejernihan seseorang dalam berpikir akan tercermin dalam bahasa lisan dan bahasa tubuhnya, bahasa verbal dapat menjadi faktor yang dapat mempengaruhi seseorang sehingga disukai oleh orang lain, segala tindakan dan perilaku seseorang dapat dipantau dengan mudah melalui bahasa verbal, dalam hal ini dapat diartikan bahwa bahasa verbal merupakan pondasi dasar seseorang untuk berinteraksi dengan lingkungannya, demikian juga pada konteks pembelajaran, pada pembelajaran verbal terdapat dua konsep penting yaitu mengenai persinggungan dan frekuensi,adanya persinggungan menjadikan sebuah peristiwa saling melengkapi dan berdekatan baik dari segi waktu dan tempat yang sama, sedangkan frekuensi mengacu pada bagaimana proses kedua peristiwa itu terjadi secara berdekatan,pentingnya pengembangan dalam asosiasi ini merupakan sebuah prinship yang sudah berjalan lama, artikel ini membahas bagaimana pembelajaran verbal tersebut, serta analisis dan tahapan- tahapan dalam belajar verbal dan manfaatnya dalam dunia pendidikan.

Belajar verbal, (verbal learning) merupakan kegiatan pembelajaran yang mendorong siswa untuk memberikan tanggapan-tanggapan yang bersifat verbal seperti sebuah kata yang bersifat verbal. Pada prinsipnya pembelajaran verbal tersusun secara terurut, memiliki hubungan kedekatan dengan cara memberikan respon mengenai sesuatu yang telah diketahui dan dihubungkan dengan yang lain misalnya kata "kursi" dan "meja" kata "jendela" dan "pintu" kedua bentuk kata tersebut memiliki kedekatan asosiasinya karna sangat erat dengan konteks situasi kehidupan manusia, terdapat dua konsep yang menjadi pokok pembahasan dalam pembelajaran verbal yaitu persinggungan dan frekuensi persinggungan menjadikan sebuah peristiwa saling terkait dan terhubung baik dari segi waktu dan tempat yang sama, sedangkan frekuensi merujuk tentang terjadinya kedua peristiwa dalam waktu yang sama (Katiran, 2017).

Herman Ebbinghaus seorang psikolog Jerman tahun 1885, pertama kali mengemukakan tentang verbal learning atau belajar verbal, dan ketertarikannnya pada kondisi dimana manusia belajar membuat asosiasi kemudian asosiasi tersebut dapat terabaikan begitu saja seiring berjalannya waktu,sebelum periode ini hal tersebut merupakan sebuah bagian yang kompleks dan tidak dapat diteliti serta diukur secara eksperimen, namun Herman Ebbinghaus mampu membuktikan pernyataanya bahwa memori manusia dapat diteliti secara tepat dan terukur, serta kondisi-kondisi pembelajaran dan memori manusia dapat diteliti secara exsperimen, dalam penelitiannya Ebbinghaus menganut ajaran filsuf ternama yakni Britis Associationist, berikut dua karakter Britis Associationist dalam pembelajaran yaitu : 
1. Meyakini bahwa manusia memperoleh suatu pengetahuan berdasarkan pengalaman yang diperoleh di dunia, dan bukan faktor bawaan yang dibawa oleh manusia sejak lahir.

2. Sebuah pemikiran yang kompleks dapat terbentuk dari gagasan- gasagan yang sederhana, pembentukan asosiasi ini tidak dipelajarai oleh filsuf, namun Ebbinghaus dapat membuktikan studi eksperimennya mengenai pembentukan asosiasi.

Berikut 4 pengembangan dalam belajar verbal:

1. Serial Learning ( Pembelajaran Berseri )

Menyajikan aspek- aspek verbal dari satu urutan yang sama keurutan yang lainnya, menghapal dan juga mengingat merupakan contoh yang paling dikenal dalam bentuk ini, urutan menghapal yang sistematis dari satu urutan keurutan selanjutnya misalnya hapalan hitungan hari di dalam satu minggu, jumlah minggu dalam satu bulan, jumlah bulan dalam satu tahun demikan selanjutnya.

2. Paired Assosiated Learning (Pembelajaran Asosiasi Berpasangan)

Dalam hal ini tugas siswa yaitu mempelajari pasangan suatu item, pasangan yang lain salah satunya bertindak sebagi stimulus sedangkan yang lainnya bertindak sebagai respon, yang paling dikenal dalam pembelajaran ini adalah mempelajari kosa kata, teknik yang digunakan yaitu memasangkan kosa kata asing dengan kosa kata yang sama dengan menggunakan bahasa ibu (Psikologi, n.d.).

\section{Free Recall ( Rekal Bebas)}

Kegiatan ini menyajikan subjek dari satu tahap item verbal kemudian suatu saat diminta untuk mengulang kembali dan merikol item tersebut tanpa memperhatikan bagian-bagian unit item, verbal disajikan secara bervariasi sehingga siswa bebas mengulang kembali tahapan -tahapan dalam item tersebut sesuai yang dikehendakinya.

\section{Recognation Learning ( Pembelajaran Rekognis )}

Kegiatan ini merupakan proses pembelajaran yang menuntut siswa untuk mampu membedakan antara peristiwa yang sudah diketahui dengan peristiwa yang belum diketahui, dalam pembelajaran ini siswa diperlihatkan item selanjutnya serta diuji dengan mengingat urutan latihan tertentu.

Teori asosiasi merupakan pendekatan dalam belajar verbal, prinsip dalam pendekatan asosiasi bahwa frekuensi pengalaman merupakan bagian penting dalam pendekatan ini, bagi para teori asosiasi metode pembelajaran baik secara serial maupun secara berpasangan merupakan metode dominan, hal ini bertujuan untuk menentukan variabel-variabel dalam pembelajaran yang dapat memberi pengaruh terhadap belajar verbal, beberapa variabel penting dalam pembelajaran verbal seperti, familiaritas item, kebermaknaan item, kemiripan dan frekuensi pengalaman item (Payong, 2017).

1. Kebermaknaan dalam belajar verbal

Clyde Noble berpendapat bahwa yang mendasari jumlah asosiasi berawal dari banyaknya kebermaknaan suatu item. Dengan demikian menurut Clyde Noble bahwa salah satu cara yang dapat digunakan untuk memahami kebermaknaan yaitu dengan cara mengukur banyaknya asosiasi terhadap sebuah kata atau unit verbalnya.kebermaknaan dalam pembelajaran asosiasi terbagi menjadi stimulus dan respon, pada hakikatnya semakin tinggi stimulus dan respon maka pembelajaran dapat diartikan semakin baik, demikian juga jika stimulus dan respon menurun maka dapat diartikan makna pembelajaran semakin rendah.

2. Kesamaan dalam belajar verbal 
Faktor lain yang dapat memberikan pengaruh terhadap pembelajaran verbal adalah faktor kesamaan,efek dari kesamaan ini tergantung dari jenis upaya pemahaman verbal yang dilakukan, terdapat tiga jenis kesamaan dalam belajar verbal yaitu kesamaan formal, kesamaan makna, dan kesamaan konsep (Cleary, 2019).

\section{METODE PENELITIAN}

Artikel ini membahas tentang analisis tahapan dalam belajar verbal, jenis metode penelitian ini adalah analisis kajian pustaka (literatur research) artikel ini akan memaparkan analisis jurnal ilmiah yang relevan dengan pembahasan yang sudah dipilih, adapun tahap- tahap dalam metode penelitian ini adalah (1) memilih artikel, (2) mengumpulkan data awal, (3) tantangan dari topik,(4) mengumpulkan data pendukung, (5) menghasilkan kesimpulan dan rekomendasi online.

\section{HASIL DAN PEMBAHASAN PENELITIAN}

Sekitar tahun 1950 sampai dengan 1960-an kajian tentang belajar verbal mulai detail dibahas hal ini berdasarkan pada tahap- tahap dan komponen- komponennya, adapun tahap-tahap dalam pembelajaran verbal diantaranya adalah:

\section{Respon and Stimulus Learning}

Dalam hal ini melalui dua tahap yaitu tahap pembelajaran respon ( Learning Response Stage) tahap yang harus kita pelajarai agar kita mampu merespon dan mengingat kembali, hal ini dilengkapi dengan tahap asosiatf merupakan tahap dimana kita memancing suatu respon tertentu terhadap suatu stimulus.

\section{Stimulus and Descrimination}

Melalui kegiatan ini siswa harus dapat mengartikan pembeda antara satu stimulus dengan stimulus lainnya, semakin besar tingkat kemiripan stimulus maka makna pembelajaran semakin baik, namun jika terdapat stimulus yang jauh berbeda dapat diartikan kebermaknaan tidak begitu jelas.

\section{Stimulus Selection}

Stimulus selection merupakan sebuah konsep yang menyajikan beberapa stimulus, dalam hal ini siswa memilih dan menggunakan satu stimulus saja karena tersaji dalam konsep yang berbedabeda. Stimulus yang dipilih bertujuan untuk memancing respon, hal ini dinamakan dengan (functional stimulus).

\section{Stimulus Coding}

Stimulus Coding merupakan konsep mengubah stimulus nominal menjadi beberapa bentuk stimulus yang baru atau dapat juga dilakukan dengan melakukan pengulangan, mengubah stimulus menjadi bentuk baru dinamakan substitution coding, sedangkan mengubah dengan memberikan informasi tambahan disebut dengan elaborating coding.

\section{Pendekatan Kognitif}

Dalam perkembangan psikologi belajar teori kognitif telah memberikan sumbangan yang begitu besar, ruang lingkup pengetahuan kognitif merupakan kumpulan psikologi kognitif, linguistik, ilmu komputer, epistemologi dan intelegensi buatan. Teori kognitif berpendapat bahwa tingkah laku manusia merupakan suatu hal yang tidak dapat diukur dan diterangkan, bahwa tingkah laku manusia merupakan sebuah proses seperti mental, motivasi, keyakinan, kesengajaan dan lain sebagainya.pandangan dalam teori kognitif bahwa tingkah laku manusia merupakan sebuah faktor mental dan bukan faktor tingkah laku, meskipun dalam proses pembelajaran tingkah laku merupakan hal nyata yang dapat dilihat. Sebagai contoh seorang anak yang sedang 
belajar membaca dan menulis menggunakan perangkat jasmani seperti mata dan tangannya untuk mengucapkan kata-kata dan menggoreskan pena, akan tetapi perilaku jasmani tersebut bukan semata-mata respon stimulus dari tingkah lakunya, melainkan respon penting dari stimulus mentalnya (Dari, Kognitif, Piaget, \& Pengolahan, 2020).

Berikut diuraikan beberapa komponen penting dalam ranah kognitif yang perlu dikembangkan:

1. Cara yang dilakukan dalam memahami materi pembelajaran

2. Cara meyakini materi pembelajaran, menyerap pesan-pesan moral dalam pembelajaran serta menerapkan materi pembelajaran dalam kehidupan

Untuk membantu mempelajari ranah kognitif berikut diuraikan aspek-aspek yang perlu diperhatikan dalam penyajian materi:

1. Pengelompokan dan Pemanggilan Kembali

Salah satu jenis dalam proses organisasi pembelajaran verbal adalah pengelompokan dan pemanggilan kembali yang artinya proses pemanggilan kembali telah diatur berdasarkan bentuk asalnya, sebagaimana proses rangkaian kata ,yang artinya pada suatu waktu kita dapat mengelompokkan dan mengorganisasikan materi verbal dan menghubungkannya antara satu kata dengan kata yang lain, jika kata demi kata tersebut terdapat hubungan, maka hal tersebut cenderung memanggil kembali sehingga hal ini disebut sebagai proses pengelompokan hubungan, contohnya, anak-anak perempuan, anak laki- laki, siang-malam, dan lain sebagainya.

\section{Pengorganisasian Subjektif}

Pengorganisasian Subjektif merupakan bentuk pemaksaan manusia itu sendiri melalui lisannya atau pada saat tidak ada organisasi dan peristiwa yang struktur.

\section{Pengkodean}

Merupakan kegiatan dalam mengubah informasi dalam bentuk sebuah tanda, sebagai contoh ketika memberikan tanda tentang hubungan silabus BYO, CIE, dan IPL dapat dirubah dalam bentuk kode BOY,ICE, dan LIP.

\section{Meditasi Bahasa Alami}

Meditasi bahasa alami merupakan salah satu tipe pada pengkodean, secara konsepnya pada tipe ini siswa dilihat sebagai agen aktif dalam mengolah sebuah informasi, ketika kita menyimpulkan makna dari sebuah informasi pada memori, maka kita dapat mengumpulkan dengan menggunakan kata, frase, atau kalimatkalimat yang dapat membantu dalam bentuk materi.

\section{Perumpamaan Mental}

Faktor yang memberikan pengaruh besar terhadap belajar verbal adalah kemampuan kita dalam menggunakan perumpamaan mental, hal ini dapat diartikan bahwa sepasang gabungan kata merupakan pasangan belajar dengan perumpamaan mental atau dengan kata lain merupakan sebuah gambar fasilitas belajar (Siyamta, 2013).

\section{Motivasi Belajar Verbal}

Menurut (Pitrinch \& Schunk dalam Sukadji \& Singgih-Salim, 2001) berpendapat motivasi belajar merupakan suatu kondisi psikologis yang mengarahkan, menuntun, serta mempertahankan tingkah laku tertentu dalam diri siswa sehingga dapat mendorong kegiatan belajar, adanya motivasi memberikan pengaruh 
yang sangat besar terhadap kegiatan belajar serta mempengaruhi suatu aktivitas.berikut diuraikan 3 aspek motiv yang dinyatakan oleh McClelland.

1. Motif untuk berhubungan dengan orang lain (Affilation Motive)

Motif ini menuntun pola tingkah laku manusia untuk berinteraksi dengan orang lain dengan tujuan dapat membina suasana yang dekat, akrab dan harmonis, yang menjadi ciri- ciri orang yang memiliki affilation motive yaitu risau apabila dijauhi teman-temannya, selalu berusaha untuk dapat diterima dalam kelompok, dan senang berada didalam suasana akrab.

2. Motif untuk Berkuasa ( Power Motiv )

Motif ini merupakan bentuk motif yang mengarah pada tingkah laku otoriter, ingin menguasai dan mendominasi dalam hubungannya dengan orang lain.

\section{Motif Berprestasi}

Merupakan bentuk motif yang mendorong seseorang menuju proses keberhasilan dalam standar keunggulan baik dari segi dirinya sendiri maupun dari orang lain, berikut diuraikan ciri-ciri orang dengan motivasi tinggi yaitu :

a. Gigih dan tidak mudah menyerah

b. Berusaha menentukan sendiri apa yang menjadi standar prestasinya

c. Menampilkan tugas yang baik pada hasil akhir

d. Didorong atas dasar kemauan sendiri bukan atas dasar hadiah

e. Cenderung memikirkan resiko dengan taraf yang sedang

f. Setiap tindakanya dievaluasi dengan umpan balik

g. Dapat mencermati lingkungan dan berusaha memanfaatkan kesempatan

h. Memiliki loyalitas yang tinggi

i. Menyenangi aktivitas yang menantang untuk memperoleh pengalaman

J. Mencari ide kreatif dalam menyelesaikan masalah (Sabiq, 2009)

Pendapat berbeda mengenai motivasi yang terbagi kedalam dua hal yaitu, motivasi yang berasal dari dalam diri seseorang, dan motivasi yang merupakan bentuk dorongan dari luar, konsep motivasi dari dalam diri yaitu siswa bersedia belajar tanpa memperoleh hadiah ataupun insentif, motivasi ini merupakan dorongan yang berasal dari individu itu sendiri, motivasi sangat diperlukan dalam diri seseorang, sebab seseorang yang tidak memiliki motivasi tidak terdorong untuk membekali dirinya melalui aktivitas dalam kegiatan pembelajaran, seseorang yang tidak memiliki motivasi dari dalam dirinya membutuhkan dorongan dari luar, oleh sebab itu, motivasi dari luar sangat dibutuhkan apabila seseorang itu kehilangan motivasi dari dalam dirinya.

\section{KESIMPULAN}

Belajar verbal (Verbal Learning) merupakan kegiatan pembelajaran yang mendorong siswa untuk memberikan respon terhadap materi verbal seperti sebuah kata dan tanggapan- tanggapan yang bersifat verbal.pada prinshipnya pembelajaran verbal tersusun secara sistematik, memiliki hubungan kedekatan dengan cara mengingat sesuatu dan dihubungkan dengan yang lain,ruang lingkup belajar verbal terdiri dari materi dan prosedur yang terurai dalam konteks- konteks pengembangan yaitu, Serial Learning, Paired Assosiated Learning, Free Recall,dan Recognation Learning. Prinsip dalam belajar verbal menganut paham teori asosiasi, prinship dalam pendekatan asosiasi bahwa frekuensi pengalaman merupakan bagian penting dalam pendekatan ini, Clyde Noble berpendapat bahwa yang mendasari jumlah asosiasi berawal dari 
banyaknya kebermaknaan, dan kesamaan suatu item, adapun tahap- tahap dalam belajar verbal yaitu, respon and stimulus learning, stimulus and descrimination, stimulus selection, dan stimulus coding.

Pendekatan yang dilakukan dalam belajar verbal yaitu menggunakan pendekatan kognitif yang terdiri dari kumpulan psikologi kognitif, linguistik, ilmu komputer, epistemologi dan intelegensi buatan. Teori kognitif berpendapat bahwa tingkah laku manusia merupakan suatu hal yang tidak dapat diukur dan diterangkan, bahwa tingkah laku manusia merupakan sebuah proses seperti mental, motivasi, keyakinan, kesengajaan dan lain sebagainya, adanya motivasi dalam belajar verbal akan mendorong siswa untuk belajar atas dasar kemauannya sendiri bukan karna hadiah atau intensif yang di peroleh, faktor motivasi terdiri dari dua hal yaitu motivasi dari dalam diri dan motivasi dari luar individu itu sendiri, bagi siswa yang tidak memiliki dari dalam diri maka sangat dibutuhkan motivasi luar yang dapat mendorong siswa untuk melakukan kegiatan belajar.

\section{DAFTAR PUSTAKA}

Cleary, M. (2019). Pembelajaran Biologi Menggunakan Pendekatan Ctl (Contextual Teaching And Learning) Melalui Media Flipchart Dan Video Ditinjau Dari Kemampuan Verbal Dan Gaya Belajar. Journal of Chemical Information and Modeling, 53(9), 1689-1699.

Dari, T. B., Kognitif, P., Piaget, T., \& Pengolahan, D. A. N. (2020). BAHAN AJAR.

Han, E. S., \& goleman, daniel; boyatzis, Richard; Mckee, A. (2019). 済無No Title No Title. Journal of Chemical Information and Modeling, 53(9), 1689-1699.

Katiran. (2017). Penggunaan Media Pembelajaran Terhadap. 11(1), 12-25.

Payong, M. R. (2017). Jejak-Jejak Epistemologis Teori Belajar Dan Pembelajaran: Sebuah Sketsa Ringkas. JIPD (Jurnal Inovasi Pendidikan Dasar), (10). Retrieved from http://jurnal.unikastpaulus.ac.id/index.php/jipd/article/view/263

Psikologi, P. (n.d.). PSIKOLOGI BELAJAR.

Sabiq, A. N. (2009). PENGARUH KEMAMPUAN VERBAL, KEMAMPUAN MATEMATIKA, DAN MOTIVASI BELAJAR TERHADAP PRESTASI BELAJAR MATA PELAJARAN AKUNTANSI SISWA KELAS 2 SMA.

Siyamta. (2013). Ranah Kognitif Dalam Pembelajaran. 